\title{
Association between methylenetetrahydrofolate reductase gene C677T polymorphism and susceptibility to polycystic ovary syndrome
}

\author{
Vandana Rai, Pradeep Kumar \\ Department of Biotechnology \\ VBS Purvanchal University \\ Jaunpur -222003, India. \\ E mail- raivandana@rediffmail.com
}

\begin{abstract}
:
Polycystic ovary syndrome (PCOS) is the most common form of endocrinopathy of women. Several studies have investigated the association of methylenetetrahydrofolate reductase (MTHFR) gene C677T polymorphism with PCOS risk but the results are contradictory. So, the aim of the present study was to carry out a meta-analysis of a published case control studies to find out exact association between MTHFR gene C677T polymorphism and PCOS susceptibility. Pubmed, Springer link, Science Direct and Google Scholar databases were searched for case-control studies. Odds ratios (ORs) with $95 \%$ confidence intervals (CIs) was used as association measure and meta-analysis was performed using MIX and MetaAnalyst programs.

Meta-analysis of 24 studies showed strong significant association between C677T polymorphism and PCOS risk (for T vs. C: $\mathrm{OR}=1.18,95 \% \mathrm{CI}=1.01-1.38, \mathrm{p}=0.03$; for TT vs. $\mathrm{CC}$ : $\mathrm{OR}=1.37,95 \% \mathrm{CI}=1.0-$ 1.89, $\mathrm{p}=0.045$; for TT + CT vs. $\mathrm{CC}: \mathrm{OR}=1.31,95 \% \mathrm{CI}=1.07-1.62, \mathrm{p}=0.008$; for CT vs. $\mathrm{CC}: \mathrm{OR}=1.31$, 95\% $\mathrm{CI}=1.04-1.62, \mathrm{p}=0.01$ and for $\mathrm{TT}$ vs. $\mathrm{CT}+\mathrm{CC}: \mathrm{OR}=1.10,95 \% \mathrm{CI}=0.82-1.47, \mathrm{p}=0.04)$. In subgroup analysis, MTHFR C677T polymorphism is significantly associated with PCOS risk with Asian individuallas but in Caucasian population MTHFR C677T polymorphism was not significantly associated with PCOS risk. In conclusion, C677T polymorphism is a risk factor for PCOS.
\end{abstract}

\section{Keywords:}

Polycystic Ovary Syndrome, PCOS, PCOD, MTHFR, C677T, meta-analysis

Introduction:

Polycystic ovary syndrome (PCOS) also known as polycystic ovary disease (PCOD) is the most common and widespread form of endocrinopathy of women of fertile, affecting up to $2-25 \%$ of women in reproductive age (Wijeyaratne et al., 2002). PCOS is characterized by oligomenorrhea or amenorrhea and hyperandrogenism (Fauser et al., 2004). It is associated with increased risk of pregnancy loss (Chang 2014). PCOS is a mutimetabolic syndrome and a risk factor for the obesity, type 2 diabetes, hypertension and dyslipidaemia (Wild et al., 1985; Talbott et al., 1995; Solomon, 1999). According to Rotterdam consensus (2003) diagnostic criteria, minimum two symptoms of the following should be present 1) clinical hyperandrogenism 2) oligoanovulation and 3) polycystic ovaries (PCO).

PCOS is a heterogeneous condition and earlier evidences and reports have suggested that the disturbed homocysteine (Hcy) methionine cycle increases concentration of homocysteine in the women, and higher concentration of homocystein is a risk factor for PCOS. Environmental and genetic factors play an important role in Hcy synthesis. Hcy is a sulfur containing amino acid and is converted into methionine in folate and methionin cycle. Methylenetetrahydrofolate reductase (MTHFR) enzyme is involved in the folate dependent remethylation of Hcy to methionine (Wu et al. 2012) and single nucleotide polymorphism (SNP) in MTHFR gene is the most common genetic defect of homocysteine metaboism. It catalyzes the conversion of 5,10-methylenotetrahydrofolate into 5-methylenotetrahydrofolate, which provides a single carbon for the methylation of homocysteine to methionine (Wu et al. 2012). C677T polymorphism (rs1801133) involves cytosine-to-thymine substitution at the 677 position (C677T), leads to an alanine-to-valine substitution at position 222 in the MTHFR enzyme. C677T polymorphism leads to thermolability of MTHFR enzyme, resulting in decreased enzyme activity (Frosst et al.,1995; Jacques et 
medRxiv preprint doi: https://doi.org/10.1101/2020.06.15.20132324; this version posted June 19, 2020. The copyright holder for this preprint (which was not certified by peer review) is the author/funder, who has granted medRxiv a license to display the preprint in perpetuity. It is made available under a CC-BY-NC 4.0 International license .

al. 1996). Frequency of C677T polymorphism is greatly varies in different global regions (Schneider et al., 1998; Wilcken et al., 2003; Spiridonova et al., 2004; Rai et al., 2010, 2012; Yadav et al., 2018).

First of all, Glueck and colleagues (1999) have reported an association between MTHFR C677T polymorphism and PCOS. Since then, several reports are published regarding MTHFR C677T polymorphism as a risk factor for PCOS with positive (Wu et al., 2016; Jiao et al., 2018; Amuhtar and Amohaidi, 2019)as we as negative (Sills et al., 2001; Lee et al., 2003; Orio et al., 2003) results. Hence, the aim of the present study was to explore whether the MTHFR C677T polymorphism is associated with susceptibility to polycystic ovary syndrome (PCOS). In the present study, authors have performed a largescale meta-analysis to find out the exact association between the MTHFR C677T polymorphism and PCOS by including data from studies that were published from 1999 until now

\section{Methods:}

\section{Article Search.}

Published articles examining the effect of the MTHFR gene C677T polymorphisms on the risk of PCOS were identified through electronic database searches in Pubmed, Science direct, Google scholar and Springer Link. Databases searches were done from January 1990 Electronic database searches were supplemented by manual searches of references of review and published research articles. The following terms were used: "methylenetetrahydrofoate reductase", "MTHFR," "C677T", "polycystic ovary syndrome" "polycystic ovary disease", "PCOS", "PCOD", "polymorphism". Literature search included all languages. If any study incuded different sample groups, authors have considered each sample group as a separate study in the meta-analysis.

\section{Inclusion criteria}

Studies included in our meta-analyses were based on the following criteria: (1) published in a peerreviewed journal , (2) detailed description of the samples tested (including sample size, ancestry of samples); and (3) data published before December 31, 2019. Articles were excluded if: (1) sample was not independent, (2) incomplete data/information, (3) family-based studies and genome-wide association studies (4) review, letter to editors and book chapters etc.

\section{Data Extraction}

Name of first author, ethnicity, country name, number of controls and cases, and number of MTHFR genotypes in PCOS cases and Controls were extracted from each selected article.

\section{Statistical Analyses:}

Meta-analysis was done according to the method of Rai et al (2014). Pooled ORs were estimated by using fixed effects (Mantel and Haenszel,1959) and random effects (DerSimonian and Laird,1986) model depending upon heterogeneity. When there is considerable heterogeneity between studies then the pooled OR is preferably estimated using the RE model (Zintzaras and Ioannidis, 2005). The between studies heterogeneity was calculated and was quantified using the $\mathrm{I}^{2}$ statistic (Higgins and Thompson,2002). Sensitivity analysis was performed to evaluate by removing the studies not in Hardy-Weinberg equilibrium (HWE). Control population of each study was tested for Hardy-Weinberg Equilibrium (HWE) using calculator available at http://ihg.gsf.de/cgi-bin/hw/hwa1.pl. Publication bias was assessed by Egger regression asymmetry test (Egger et a.,1997). P values were two-tailed with a significance level of 0.05. All statistical analyses were performed using computer programs Meta-Analyst (Wallace et al.,2013) and Mix version 1.7 (Bax et al.,2006).

\section{Results:}

\section{Literature Search:}

Electronic database search yielded 161 studies, after applying strict inclusion and exclusion criteria total 23 articles were found suitable for the inclusion in the present meta-analysis.. Figure 1 shows the different phases of the study selection. Information was collected from 22 articles that associated MTHFR gene C677T polymorphism and PCOS (Glueck et al., 1999; Sills et al., 2001; Tsanadis et al., 2002; Lee et al., 2003; Orio et al., 2003; Palep-Singh et al., 2007; Choi et al., 2009; Bayram et al., 2010; Karadeniz et al., 2010; Idali et al., 2012; Jain et al 2012; Kazeerooni et al., 2013; Jiang et al., 2015; Naghavi et al., 2015; Qi et al., 2015; Carlus et al., 2016; Geng et al., 2016; Ozegowska et al., 2016; Sazafarowska et al., 2016 ; Wu et al., 2016; Jiao et al., 2018; Amuhtar and Amohaidi, 2019) (Table 1). In two studies, authors 
medRxiv preprint doi: https://doi.org/10.1101/2020.06.15.20132324; this version posted June 19, 2020. The copyright holder for this preprint (which was not certified by peer review) is the author/funder, who has granted medRxiv a license to display the preprint in perpetuity. It is made available under a CC-BY-NC 4.0 International license .

(Palep-Singh et al., 2007; Carlus et al., 2016) included two group of samples.. So, in present metaanalysis, both dataset were included as separate study, and the number of included studies were twenty four.

\section{Characteristic of Eligible Studies:}

The included studies were published between 1999 and 2019. A total of 2562 cases and 2587 controls were analyzed. The analysis included Caucasian samples in 10 studies and Asian samples in 14 studies (Table 1).

The prevalence of homozygotes (CC) among PCOS cases and healthy controls were $41.64 \%$ and $49.67 \%$, respectively. The prevalence of heterozygotes (CT) among PCOS patients and controls were $41.26 \%$ and $36.72 \%$, respectively. The prevalence of mutant homozygote (TT) among PCOS cases and the controls were $17.45 \%$ and $14.15 \%$, respectively. In the PCOS cases, C allele was the most frequent: $62.06 \%$ whereas the frequency of the $\mathrm{T}$ allele was $37.94 \%$. In the control group, the prevalence of $\mathrm{C}$ allele was $67.67 \%$, and the prevalence of $\mathrm{T}$ allele was $32.33 \%$ (Figure 2). In four studies (Bayram et al., 2010; Karadeniz et al., 2010; Kazeerooni et al., 2013; Ozegowska et al., 2015), control genotypes were not in Hardy-Weinberg equilibrium $(\mathrm{P}<0.05)$. All genetic models; -allele contrast ( $\mathrm{T}$ vs $\mathrm{C}$ ) homozygote (TT vs CC), co-dominant (CT vs CC), dominant (TT+CT vs CC) and recessive (TT vs CT+CC) models were used to evaluate C677T polymorphism as PCOS risk.

\section{Meta-analysis:}

Table 2 summarizes the ORs with corresponding 95\% CIs for association between $\mathrm{T}$ polymorphism and risk of PCOS in allele contrast, co-dominant, homozygote dominant, and recessive models. Metaanalysis of allele contrast ( $\mathrm{T}$ vs. C) model showed significant association with both fixed effect $\left(\mathrm{OR}_{\mathrm{TvsC}}=\right.$ $1.28 ; 95 \% \mathrm{CI}=1.17-1.40 ; \mathrm{p}=<0.0001)$ and random effect model $\left(\mathrm{OR}_{\mathrm{TvSC}}=1.18 ; 95 \% \mathrm{CI}=1.01-1.38 ; \mathrm{p}=\right.$ 0.03). Subjects with PCOS cases showed a significantly increased frequency of the T allele in comparison to control. (Table 2).

Meta-analysis of twenty five studies showed an increased risk of PCOS among mutant homozygote variants (TT vs. CC; homozygote model), with both fixed $\left(\mathrm{OR}_{\mathrm{TTv} \text { sCC }}=1.62 ; 95 \% \mathrm{CI}=1.34-1.96 ; \mathrm{p}\right.$ $<0.0001)$ and random $\left(\mathrm{OR}_{\mathrm{TTvSCC}}=1.39 ; 95 \% \mathrm{CI}=1.0-1.89 ; \mathrm{p}=0.04\right)$ effect models (Table 2, Figure 3). Association of heterozygous genotype (CT vs. CC; co-dominant model) was also observed significant with both fixed $\left(\mathrm{OR}_{\mathrm{CTvSCC}}=1.34 ; 95 \% \mathrm{CI}=1.17-1.59 ; \mathrm{p}<0.0001\right)$ and random $\left(\mathrm{OR}_{\mathrm{CTvSCC}}=1.31 ; 95 \% \mathrm{CI}=\right.$ 1.04-1.62; $\mathrm{p}=0.02$ ) effect models (Table 2). Combined mutant genotypes (TT + CT vs.CC; dominant model $)$ showed positive association with $\mathrm{PCOS}$ using both fixed $\left(\mathrm{OR}_{\mathrm{TT}+\mathrm{CTvSCC}}=1.39 ; 95 \% \mathrm{CI}=1.23-1.58\right.$; $\mathrm{p}<0.0001)$ and random $\left(\mathrm{OR}_{\mathrm{TT}+\mathrm{CT} \text { vsCC }}=1.31 ; 95 \% \mathrm{CI}=1.07-1.62 ; \mathrm{p}=0.008\right)$ effect models (Table 2). Similarly the recessive genotypes model (TT vs. CT $+\mathrm{CC}$ ) also showed positive association with PCOS using both fixed $\left(\mathrm{OR}_{\mathrm{TTvsCT}+\mathrm{CC}}=1.32 ; 95 \% \mathrm{CI}=1.12-1.55 ; \mathrm{p}=0.0007\right)$ and random $\left(\mathrm{OR}_{\mathrm{TTvsCT}+\mathrm{CC}}=1.10\right.$; 95\% CI $=0.82-1.47 ; \mathrm{p}=0.041$ ) effect models (Table 2).

\section{Sub-group Analysis:}

Out of 24 studies 16 studies (2023 cases and 1959 controls) were Asian region and 8 studies (539 cases and 628 controls) from Caucasian population. Meta-analysis of Asian studies revealed that except recessive model, a other four models showed significant association between MTHFR C677T polymorphism and PCCOS risk (for T vs. $\mathrm{C}$ : $\mathrm{OR}=1.29,95 \% \mathrm{CI}=1.06-1.57, \mathrm{p}=0.03$; for TT vs. $\mathrm{CC}$ : $\mathrm{OR}=$ $1.38,95 \% \mathrm{CI}=0.91-2.11, \mathrm{p}=0.05$; for $\mathrm{TT}+\mathrm{CT}$ vs. $\mathrm{CC}: \mathrm{OR}=1.48,95 \% \mathrm{CI}=1.13-1.92, \mathrm{p}=0.004$; for $\mathrm{CT}$ vs. $\mathrm{CC}: \mathrm{OR}=1.49,95 \% \mathrm{CI}=1,12-1.92, \mathrm{p}=0.005$ and for $\mathrm{TT}$ vs. $\mathrm{CT}+\mathrm{CC}: \mathrm{OR}=1.08,95 \% \mathrm{CI}=0.74-$ $1.58, \mathrm{p}=0.68$ ) (Figure 4).

Meta-analysis of Caucasian studies did not show any association between PCOS susceptibility and MTHFR C677T polymorphism (for T vs. $\mathrm{C}$ : $\mathrm{OR}=1.04,95 \% \mathrm{CI}=0.83-1.30, \mathrm{p}=0.31$; for $\mathrm{TT}+\mathrm{CT}$ vs. $\mathrm{CC}: \mathrm{OR}=1.07,95 \% \mathrm{CI}=0.85-1.35, \mathrm{p}=0.54$; for $\mathrm{TT}$ vs. $\mathrm{CC}: \mathrm{OR}=1.29,95 \% \mathrm{CI}=0.87-1.91, \mathrm{p}=0.19$ ) (Figure 5).

Heterogeneity analysis:

A true heterogeneity existed between studies in allele contrast $\left(\mathrm{P}_{\text {heterogeneity }}=<0.001, \mathrm{Q}=59.15, \mathrm{df}=24, \mathrm{I}^{2}=\right.$ $\left.61.12 \%, \mathrm{t}^{2}=0.08\right)$, co-dominant $\left(\mathrm{P}_{\text {heterogeneity }}=0.0002, \mathrm{Q}=54.65, \mathrm{df}=24, \mathrm{I}^{2}=57.92 \%, \mathrm{t}^{2}=0.15\right)$, 
homozygote $\left(\mathrm{P}_{\text {heterogeneity }}=0.001, \mathrm{Q}=44.74, \mathrm{df}=24, \mathrm{I}^{2}=53.06 \%, \mathrm{t}^{2}=0.25\right)$ and dominant genotypes $\left(\mathrm{P}_{\text {heterogeneity }}=0.0002, \mathrm{Q}=54.74, \mathrm{df}=24, \mathrm{I}^{2}=57.99 \%, \mathrm{t}^{2}=0.14\right)$ comparisons. The ' $\mathrm{I}^{2}$, value was more than $50 \%$ in allele and a genotype comparisons, showed high level of true heterogeneity. Allele contrast metaanalysis of Asian studies showed significant higher heterogeneity $\left(\mathrm{P}_{\text {heterogeneity }}=0.0004, \mathrm{I}^{2}=69.39 \%\right)$, but in Caucasian studies meta-anaysis true heterogeneity was absent $\left(\mathrm{P}_{\text {heterogeneity }}=0.34, \mathrm{I}^{2}=11.06 \%\right)$.

\section{Sensitivity analysis:}

In sensitivity analysis, allele contrast meta-analysis was performed after exclusion of four studies (Bayram et al., 2010; Karadeniz et al., 2010; Kazeerooni et al., 2013; Ozegowska et al., 2015) in which control population was not in HWE. Exclusion of four studies not in HWE did not affect heterogeneity and also did not increase the odds ratio.

\section{Publication bias:}

Precision and standard error Funnel plots are symmetrical and p-value of Eggers test, is higher than 0.05 (except recessive mode), showing the absence of publication bias (for $\mathrm{T} v \mathrm{v}$. $\mathrm{C}: \mathrm{P}_{\mathrm{Pb}}=0.07$; for $\mathrm{CT}$ vs. CC: $\mathrm{P}_{\mathrm{Pb}}=0.77$; for TT vs. $\mathrm{CC}: \mathrm{P}_{\mathrm{Pb}}=0.05$; for TT+CT vs. $\mathrm{CC}: \mathrm{P}_{\mathrm{Pb}}=0.41$; and for TT vs. $\mathrm{CT}+\mathrm{CC}: \mathrm{P}_{\mathrm{Pb}}=0.01$ ) (Figure 6).

\section{Discussion:}

Several experimental and clinical evidences suggested that disturbances in folate (either deficiency or excess) and homocystein-methionine cycles resulted in ovarian dysfunctions-(i) ovulation in immature superovulated rats inhibited (Willmott et al., 1968; Wang et al., 2017),(ii) monkeys have degenerated Graffian follicles and an increase in atretic and cystic follicles (Mohanty and Das,1982; Wang et al., 2017) and (iii) homocysteine levels in PCOS cases and homocysteine levels returned to normal levels following folic acid supplementation (Bayraktar et al., 2004; Badawy et al., 2007; Kazerooni et al., 2007 ; Wang et al., 2017). In present meta-analysis, we tried to find out the exact associations between MTHFR C677T polymorphism and PCOS susceptibility. Our results indicated that the MTHFR polymorphism is risk factor for PCOS and OR is statistically significant $(\mathrm{OR}=1.31 ; 95 \% \mathrm{CI}=1.07-1.62$; $\mathrm{p}=0.008)$.

Meta-analysis is a powerful strategy to find out the effects of genes in susceptibility of different diseases/disorders. In past two decades, numerous meta-analysis were published to evaluate the risk of genes polymorphism for different disease/ disorders- MTRR gene frequency (Yadav et al.,2019), down syndrome (Rai,2011; Rai et al., 2017; Rai and Kumar, 2018), cleft lip and palate (Rai, 2017), Gucose-6phosphate dehydrogenas deficiency (Kumar et al.,2016), recurrent pregnancy loss (Rai,2014,2016), male infertility (Rai and Kumar, 2017), autism (Rai, 2016), schizophrenia (Rai et al., 2017), obsessive compulsive disorder (Kumar and Rai,2019), depression (Rai,2014,2017), epilepsy (Rai and Kumar,2018), Alzheimers disease (Rai, 2016), esophageal cancer (Kumar and Rai, 2018), prostate cancer (Yadav et al.,2016), breast cancer (Rai et al.,2017), endometrial cancer (Kumar et al., 2018) colorectal cancer (Rai, 2015), uterine leiomyioma (Kumar and Rai,2018), and ovary cancer (Rai , 2016).

Several limitations of this meta-analysis should be considered such as (i) crude OR calculated, (ii) presence of higher between heterogeneity, and (iii) included singe gene polymorphism. In addition to limitations, present meta-analysis also have several strengths like- absence of publication bias, inclusion of large number of studies as well as large sample size.

In conclusion, the results indicate that the MTHFR C677T polymorphism is risk factor for PCOS $(\mathrm{OR}=$ $1.31 ; \mathrm{p}=0.008)$. Subgroup analysis based on ethnicity also confirmed the results that MTHFR C677T polymorphism is risk factor for PCOS in Asians but not in Caucasian population. In future, Studies with larger sample sizes from different population of globe are required to come to conclusion regarding MTHFR C677T polymorphism and PCOS association.

\section{Compliance with Ethical Standards:}

\section{Conflict of Interest: None}


medRxiv preprint doi: https://doi.org/10.1101/2020.06.15.20132324; this version posted June 19, 2020. The copyright holder for this preprint (which was not certified by peer review) is the author/funder, who has granted medRxiv a license to display the preprint in perpetuity. It is made available under a CC-BY-NC 4.0 International license .

Informed consent and Ethical Clearance are not required, as there was no human or animal involvent in the present study

\section{Sources of financial support: Nil}

\section{References:}

Almukhtar AA, Almohaidi AMS.2019. Investigation for variation in MTHFR gene in iraqi arab female with PCOS. Asian Jr. of Microbiol. Biotech. Env. Sc. 21. (4) : 851-861

Badawy A, State O, El Gawad SSA, El Aziz OA. Plasma homocysteine and polycystic ovary syndrome: the missed link. Eur J Obstet Gynecol Reprod Biol. 2007; 131:68-72.

Bax L, Yu LM, Ikeda N, Tsuruta H, Moons KG (2006) Development and validation of MIX: comprehensive free software for meta-analysis of causal research data. BMC Med Res Methodol 6:50-58.

Bayraktar F, Dereli D, Ozgen AG, Yilmaz C. Plasma homocysteine levels in polycystic ovary syndrome and congenital adrenal hyperplasia. Endocr J 2004;51:601-608.

Carlus SJ, Sarkar S, Bansal SK, Singh V, Singh K, Jha RK, Sadasivam N, Sadasivam SR, Gireesha PS, Thangaraj K, Rajender S. Is MTHFR 677 C\&gt;T Polymorphism Clinically Important in Polycystic Ovarian Syndrome (PCOS)? A Case-Control Study, Meta-Analysis and Trial Sequential Analysis. PLoS One. 2016; 11:e0151510.

Chan Y, Zi F, Wu X, Ma L, Meng Y, Chen J (2012). Note of clarification of data in the meta-analysis of methylenetetrahydrofolate reductase C677T polymorphisms in polycystic ovary syndrome. Mol Hum Reprod. 18: 514-515.

Chang RJ (2014). Polycystic Ovary Syndrome and Hyperandrogenic States. Yen \& Jaffe's Reproductive Endocrinology. Strauss JS, Barbieri RL. Philadelphia, Elsevier/Saunders, p. 485.

Choi SW, Gu BH, Ramakrishna S, Park JM, Baek KH. Association between a single nucleotide polymorphism in MTHFR gene and polycystic ovary syndrome. Eur J Obstet Gynecol Reprod Biol. 2009; $145: 85-8$.

DerSimonian R, Laird N (1986) Meta-analysis in clinical trials. Controlled Clin Trials 7: 177-188.

Egger M, Davey Smith G, Schneider M, Minder C (1997) Bias in meta-analysis detected by a simple, graphical test. BMJ 315: 629-34.

ESHRE Capri Workshop Group. Hormones and cardiovascular health in women. Hum Reprod Update 2006;12(5):483-497.

Fauser BCJM, Chang J, Azziz R, Lobo R. 2004.Revised 2003 consensus on diagnostic criteria and longterm health risks related to polycystic ovary syndrome (PCOS). Human Reproduction 19(1):41-47.

Forges T, Monnier-Barbarino P, Alberto JM, Guéant-Rodriguez RM, Daval JL, Guéant JL. Impact of folate and homocysteine metabolism on human reproductive health. Hum Reprod Update 2007;13:225238. 
medRxiv preprint doi: https://doi.org/10.1101/2020.06.15.20132324; this version posted June 19, 2020. The copyright holder for this preprint (which was not certified by peer review) is the author/funder, who has granted medRxiv a license to display the preprint in perpetuity. It is made available under a CC-BY-NC 4.0 International license .

Framingham Offspring Study. Fasting plasma homocysteine levels in the insulin resistance syndrome: the Framingham offspring study. Diabetes Care 2001;24(8):1403-1410.

Frosst P, Blom HJ, Milos R, Goyette P, Sheppard CA, Matthews RG, Boers GJ, den Heijer M, Kluijtmans LA, van den Heuvel LP, Rozen R. A candidate genetic risk factor for vascular disease: a common mutation in methylenetetrahydrofolate reductase. Nat Genet. 1995; 10:111-3.

Fu LY, Dai LM, Li XG, Zhang K, Bai Y (2014). Association of methylenetetrahydrofolate reductase gene C677T polymorphism with polycystic ovary syndrome risk: a systematic review and metaanalysis update. Eur J Obstet Gynecol Reprod Biol. 172: 56-61.

Geng J, Zhang C, Hu S, Zhang Y, Zhang S, Lu J, Xie J, Zhao H. Role of methylenetetrahydrofolate reductase genetic polymorphisms in polycystic ovary syndrome risk. Int J Clin Exp Pathol. 2016; 9:85327.

Glueck CJ, Wang P, Fontaine RN, Sieve-Smith L, Tracy T, Moore SK (1999). Plasminogen activator inhibitor activity: an independent risk factor for the high miscarriage rate during pregnancy in women with polycystic ovary syndrome. Metabolism. 48: 1589-1595.

Gmyrek GB, Sozanski R, Jerzak M, Chrobak A, Wickiewicz D, Skupnik A, et al. (2005). Evaluation of monocyte chemotactic protein-1 levels in peripheral blood of infertile women with endometriosis. Eur J Obstet Gynecol Reprod Biol. 122: 199-205.

Gul OB, Somunkiran A, Yucel O, Demirci F, Ozdemir I. The effect of ethinyl estradiol-cyproterone acetate treatment on homocysteine levels in women with polycystic ovary syndrome. Arch Gynecol Obstet 2008;277:25-30.

Guzelmeric K, Alkan N, Pirimoglu M, Unal O, Turan C. Chronic inflammation and elevated homocysteine levels are associated with increased body mass index in women with polycystic ovary syndrome. Gynecol Endocrinol 2007;23:505-510.

Hak AE, Polderman KH, Westendorp IC, Jakobs C, Hofman A, Witteman JC, Stehouwer CD. Increased plasma homocysteine after menopause. Atherosclerosis 2000;149:163-168.

Henning BF, Tepel M, Riezler R, Gillessen A, Doberauer C. Vitamin supplementation during weight reduction-favourable effect on homocysteine metabolism. Res Exp Med (Berl) 1998;198:37-42.

Higgins JP, Thompson SG (2002) Quantifying heterogeneity in a meta-analysis. Stat Med 21: 1539-1558.

Homocysteine Studies Collaboration. Homocysteine and risk of ischemic heart disease and stroke: a meta-analysis. JAMA 2002;288(16):2015-2022.

Idali F, Zareii S, Mohammad-Zadeh A, Reihany-Sabet F, Akbarzadeh-Pasha Z, Khorram-Khorshid HR (2012). Plasminogen activator inhibitor 1 and methylenetetrahydrofolate reductase gene mutations in iranian women with polycystic ovary syndrome. Am J Reprod Immunol. 68: 400-407.

Isotalo PA, Wells GA, Donnelly JG (2000). Neonatal and fetal methylenetetrahydrofolate reductase genetic polymorphisms: an examination of C677T and A1298C mutations. Am J Hum Genet. 67: 986-90. 
medRxiv preprint doi: https://doi.org/10.1101/2020.06.15.20132324; this version posted June 19, 2020. The copyright holder for this preprint (which was not certified by peer review) is the author/funder, who has granted medRxiv a license to display the preprint in perpetuity. It is made available under a CC-BY-NC 4.0 International license .

Jacques PF, Bostom AG, Williams RR, Ellison RC, Eckfeldt JH, Rosenberg IH, et al. (1996). Relation between folate status, a common mutation in methylenetetrahydrofolate reductase, and plasma homocysteine concentrations. Circulation. 93: 7-9.

Jain M, Pandey P, Tiwary NK, Jain S. MTHFR C677T polymorphism is associated with hyperlipidemia in women with polycystic ovary syndrome. J Hum Reprod Sci. 2012; 5:52-6.

Jiang et al., 2015 Jiang Y, Lu Y, Li Y, Zhu P, Yang Q. Study on the correlation between methylene tetrahydrofolate reductase gene polymorphism and polycystic ovary syndrome. Matern Child Heal Care China. 2015; 30:3831-3.

Jiao, X., Chen, W., Zhang, J., Wang, W., Song, J., Chen, D., Zhu, W., Shi, Y., Yu, X., 2018. Variant alleles of the ESR1, PPARG, HMGA2, and MTHFR genes are associated with polycystic ovary syndrome risk in a Chinese population: a case-control study. Front. Endocrinol. 9, 504.

Karadeniz M, Erdogan M, Zengi A, Eroglu Z, Tamsel S, Olukman M (2010). Methylenetetrahydrofolate reductase C677T gene polymorphism in Turkish patients with polycystic ovary syndrome. Endocrine. 38: $127-133$.

Kazerooni T, Ghaffarpasand F, Asadi N et al. Correlation between thrombophilia and recurrent pregnancy loss in patients with polycystic ovary syndrome: a comparative study. J Chin Med Assoc. 2013; 76(5):282-288.

Kobashi G, Kato EH, Morikawa M, Shimada S, Ohta K, Fujimoto S et al. (2005). MTHFR C677T Polymorphism and factor V Leiden mutation are not associated with recurrent spontaneous abortion of unexplained etiology in Japanese women. Semin Thromb Hemost. 31: 266-71.

Kumar P, Yadav U, Rai V. (2016). Prevalence of glucose 6-pohsphate dehydrogenase deficiency in India: An updated meta-analysis. Egypt J Med Hum Genet. 2016; 17: 295-302.

Kumar P, Rai V. MTHFR C677T polymorphism and risk of esophageal cancer: An updated metaanalysis. Egyptian Journal of Medical Human Genetics. 2018; 19: 273-284.

Kumar P, Rai V. (2018).Catechol-O-Methyltransferase Val158Met polymorphism and susceptibility to Uterine Leiomyoma. Jacobs Journal of Gynecology and Obstetrics,5(1): 043.

Kumar P, Singh G, Rai V. (2020). Evaluation of COMT Gene rs4680 polymorphism as a risk factor for endometrial cancer. Ind J Clin Biochem. 35(1):63-71.

Kumar P, Rai V. (2020). Catechol-O-methyltransferase gene Val158Met polymorphism and obsessive compulsive disorder susceptibility: a meta-analysis. Metab. Brain Dis. 35:242-251.ISSN 0885-7490.

Lee, K.W., Jeong, Y.M., Lee, S.H., Yoon, T.K., Kwak, I.P., Yoon, S.W., Choi, J.S., Kim, K.H., Han, J.S., Kim, S.D., 2003. The study of 5,10-methylenetetrahydrofolate reductase variation (MTHFR C677T) in infertile females with polycystic ovarian syndrome (PCOS) in Korea. Kor. J. Fertil. Steril. 30, 217-222.

Mantel N, and Haenszel W (1959): Statistical aspects of the analysis of data from retrospective studies of disease. J Natl Cancer Inst 22(4): 719-48.

Mohanty D, Das KC. Effect of folate deficiency on the reproductive organs of female rhesus monkeys: a cytomorphological and cytokinetic study. J Nutr. 1982; 112:1565-76. 
medRxiv preprint doi: https://doi.org/10.1101/2020.06.15.20132324; this version posted June 19, 2020. The copyright holder for this preprint (which was not certified by peer review) is the author/funder, who has granted medRxiv a license to display the preprint in perpetuity. It is made available under a CC-BY-NC 4.0 International license .

Naghavi A, Mozdarani H, Garshasbi M, Yaghmaei M. 2015. Prevalence of Methylenetetrahydrofolate Reductase C677T Polymorphism in women with Polycystic Ovary Syndrome in southeast of Iran. Journal of Medicine and Life Vol. 8, 2015, 229-232.

Orio F Jr, Palomba S, Di Biase S, Colao A, Tauchmanova L, Savastano S, Labella D, et al. Homocysteine levels and C677T polymorphism of methylenetetrahydrofolate reductase in women with polycystic ovary syndrome. J Clin Endocrinol Metab 2003;88:673-679.

Ożegowska K, Bogacz A, Bartkowiak-Wieczorek J, Seremak-Mrozikiewicz A, Pawelczyk L. Is there an association between the development of metabolic syndrome in PCOS patients and the C677T MTHFR gene polymorphism? Ginekol Pol. 2016; 87:246-53.

Palep-Singh M, Picton HM, Yates ZR, Barth JH, Balen AH (2007). Plasma homocysteine concentrations and the single nucleotide polymorphisms in the methionine synthase gene (MTR 2756A $>\mathrm{G}$ ): Associations with the polycystic ovary syndrome An observational study. Eur J Obstet Gynecol Reprod Biol. 138: 180-186.

Qi, Q., Zhang, H., Yu, M., Wang, X., Wang, Z., Xu, L., Wang, J., Mu, H., 2015. Association of methylenetetrahydrofolate reductase gene polymorphisms with polycystic ovary syndrome. Chin. J. Med. Genet. 32, 400-404.

Rai V, Yadav U, Kumar P, Yadav SK (2010) Methyleletetrahydrofolate reductase polymorphism (C677T) in Muslim population of Eastern Uttar Pradesh, India. Ind J Med Sci 64(5): 219-223.

Rai V. (2011). Polymorphism in folate metabolic pathway gene as maternal risk factor for Down syndrome. Int J Biol Med Res., 2(4): 1055-1060.

Rai V, Yadav U, Kumar P (2012) Genotype Prevalence and Allele Frequencies of 5,10Methylenetetrahydrofolate Reductase (MTHFR) C677T Mutation in two Caste Groups of India. Cell Mol Biol 58: OL1695- 701.

Rai V, Yadav U, Kumar P, Yadav SK, Mishra OP. 2014.Maternal Methylenetetrahydrofolate Reductase C677T Polymorphism and Down Syndrome Risk: A Meta-Analysis from 34 Studies. PLOS ONE 9 e108552.

Rai V (2014) Genetic polymorphisms of methylenetetrahydrofolate reductase (MTHFR) gene and susceptibility to depression in Asian population: a systematic meta-analysis. Cell. Mol. Biol. 2014; 60 (3): 29-36.

Rai V (2014). Methylenetetrahydrofolate reductase gene A1298C polymorphism and susceptibility to recurrent pregnancy loss: a meta-analysis. Cell Mol Biol. 27: 27-34.

Rai V (2016) Methylenetetrahydrofolate reductase C677T polymorphism and recurrent pregnancy loss risk in Asian population: a meta-analysis. Ind J Clin Biochem 31:402-413

Rai V (2016) Association of methylenetetrahydrofolate reductase (MTHFR) gene C677T polymorphism with autism: evidence of genetic susceptibility. Metab Brain Dis 31:727-735.

Rai V (2016) Folate pathway gene methylenetetrahydrofolate reductase C677T polymorphism and Alzheimer disease risk in Asian population. Indian J Clin Biochem 31(3): 245-52. 
medRxiv preprint doi: https://doi.org/10.1101/2020.06.15.20132324; this version posted June 19, 2020. The copyright holder for this preprint (which was not certified by peer review) is the author/funder, who has granted medRxiv a license to display the preprint in perpetuity. It is made available under a CC-BY-NC 4.0 International license .

Rai V (2016) Methylenetetrahydrofolate reductase gene C677T polymorphism and its association with ovary cancer. J Health Med Informat 7: 3-7.

Rai V (2016) Evaluation of the MTHFR C677T polymorphism as a risk factor for colorectal cancer in Asian populations. Asian Pac J Cancer Prev 16(18): 8093-8100.

Rai V, Yadva U, Kumar P (2017) Null association of maternal MTHFR A1298C polymorphism with Down syndrome pregnancy: An updated meta-analysis. The Egyptian J Med Hum Genet 18(1): 9-18.

Rai V, Kumar P (2017) Methylenetetrahydrofolate reductase C677T polymorphism and risk of male infertility in Asian population. Ind J Clin Biochem 32(3): 253-226.

Rai V. (2017). Association of C677T polymorphism (rs 1801133) in MTHFR gene with depression. Cell Mol Biol, 2017;63(6):60-67.

Rai V, Yadav U, Kumar P, Yadav SK, Gupta S (2017) Methylenetetrahydrofolate Reductase A1298C Genetic Variant and Risk of Schizophrenia: an updated meta-analysis. Indian J Med Res 145(4):437.

Rai V (2017) Strong association of C677T polymorphism of methylenetetrahydrofolate reductase gene with nosyndromic cleft lip/palate (nsCL/P). Ind J Clin Biochem 33(1):5-15.

Rai V, Kumar P (2018) Fetal MTHFR C677T polymorphism confers no susceptibility to Down Syndrome: evidence from meta-analysis. Egyptian J Med Hum Genet 19: 53-58.

Rai V, Kumar P (2018) Methylenetetrahydrofolate reductase C677T polymorphism and susceptibility to epilepsy. Neurological Sciences doi.org/10.1007/s10072-018-3583-z.

Rai V, Yadav U, Kumar P (2017) Impact of Catechol-O-Methyltransferase Val 158Met (rs4680) Polymorphism on breast cancer Susceptibility in Asian population. Asian Pac J Cancer Prev 18 (5): 1243-1250.

Rotterdam, E.A.-S.P., 2004. Revised 2003 consensus on diagnostic criteria and long-term health risks related to polycystic ovary syndrome (PCOS). Hum. Reprod. 19, 41-47

Schneider JA, Rees DC, Liu YT, Clegg JB. Worldwide distribution of a common methylenetetrahydrofolate reductase mutation. Am J Hum Genet. 1998;62:1258-60.

Sills ES, Genton MG, Perloe M, Schattman GL, Bralley JA, Tucker MJ. Plasma homocysteine, fasting insulin, and androgen patterns among women with polycystic ovaries and infertility. J Obstet Gynaecol Res 2001;27:163-168.

Solomon CG.1999. The Epidemiology of Polycystic Ovary Syndrome. Prevalence and Associated Disease Risks. Endocrinol Metab Clin North Am 28(2):247-63.

Spiridonova MG, Stepanov VA, Maksimova NR, Puzyrev VP. Population study of frequency of methylenetetrahydrofolate reductase C677T gene polymorphism in Yakutia. Genetika. 2004;40:704-8. 
medRxiv preprint doi: https://doi.org/10.1101/2020.06.15.20132324; this version posted June 19, 2020. The copyright holder for this preprint (which was not certified by peer review) is the author/funder, who has granted medRxiv a license to display the preprint in perpetuity. It is made available under a CC-BY-NC 4.0 International license .

Szafarowska M, Segiet A, Jerzak MM. Methyle notetrahydrololate reductase A1298C and C677T polymorphisms and adverse pregnancy outcome in women with PCOS. Neuro Endocrinol Lett. 2016; 37:141-6.

Talbott E, Guzick D, Clerici A, Berga S, Detre K, Weimer K, Kuller L .1995Coronary Heart Disease Risk Factors in Women With Polycystic Ovary Syndrome. Arterioscler Thromb Vasc Biol . 1995 Jul;15(7):821-6.

Tsanadis G, Vartholomatos G, Korkontzelos I, Avgoustatos F, Kakosimos G, Sotiriadis A, Tatsioni A, Eleftheriou A, Lolis D. Polycystic ovarian syndrome and thrombophilia. Hum Reprod. 2002; 17:314-9.

Wild et al., 1985; Talbott et al., 1995;Michelmore et al., 1999; Solomon, 1999

Wallace BC, Dahabreh IJ, Trikalinos TA, Lau J, Trow P, Schmid CH (2013) Closing the gap between methodologists and end-users: R as a computational back-end. J Stat Softw 49: 1-15.

Wang L, Xu W, Wang C, Tang M, Zhou Y. Methylenetetrahydrofolate reductase C677T polymorphism and the risks of polycystic ovary syndrome: an updated meta-analysis of 14 studies. Oncotarget, 2017, Vol. 8, (No. 35), pp: 59509-59517.

Wijeyaratne CN, Balen AH, Barth JH, Belchetz PE (2002). Clinical manifestations and insulin resistance (IR) in polycystic ovary syndrome (PCOS) among South Asians and Caucasians: is there a difference? Clin Endocrinol (Oxf). 57: 343-350.

Wilcken B, Bamforth F, Li Z, Zhu H, Ritvanen A, Renlund M, et al. Geographical and ethnic variation of the $677 \mathrm{C}[\mathrm{T}$ allele of 5,10 methylenetetrahydrofolate reductase (MTHFR): findings from over 7000 newborns from 16 areas world-wide. J Med Genet. 2003;40:619-25.

Wu W, Shen O, Qin Y, Lu J, Niu X, Zhou Z et al. (2012). Methylenetetrahydrofolate reductase C677T polymorphism and the risk of male infertility: a meta-analysis. Int J Androl. 35: 18-24.

Wu, J.B., Zhai, J.F., Yang, J., 2016. Role of methylenetetrahydrofolate reductase C677T and A1298C polymorphisms in polycystic ovary syndrome risk. Genet. Mol. Res. 15 (gmr15048570).

Yadav U, Kumar P, Gupta S, Rai V. (2018). Distribution of MTHFR C677T Gene Polymorphism in Healthy North Indian Population and an Updated Meta-analysis. Ind J Clin Biochem. 32(4), 399-410. ISSN: 0974-0422.

Yadav U, Kumar P, Rai V. (2016). Role of MTHFR A1298C gene polymorphism in the etiology of prostate cancer: a systematic review and updated meta-analysis. Egyptian Journal Medical Human Genetics. 17(2): 141-148.

Yadav U, Kumar P, Rai V. (2018).NQO1 gene C609T polymorphism (dbSNP: rs1800566) and digestive tract cancer risk: A Meta analysis. Nutrition and Cancer. 10.1080/01635581.20. 
medRxiv preprint doi: https://doi.org/10.1101/2020.06.15.20132324; this version posted June 19, 2020. The copyright holder for this preprint (which was not certified by peer review) is the author/funder, who has granted medRxiv a license to display the preprint in perpetuity.

It is made available under a CC-BY-NC 4.0 International license .

Yadav U, Kumar P, Rai V. (2019). Distribution of Methionine Synthase Reductase (MTRR) Gene A66G Polymorphism in Indian Population. Ind $J$ Clin Biochem. ISSN: 0974-0422. https://doi.org/10.1007/s12291-019-00862-9.

Zintzaras E, Ioannis S.2005. Association between the GLUT1 gene polymorphism and the risk of diabetic nephropathy: a meta-analysis. J Hum Genet (2005) 50:84-91.

Table 1. Details of 24 included studies

\begin{tabular}{|l|l|c|c|c|}
\hline Study & Country & Control no. & Case no. & HWE \\
\hline Glueck et al., 1999 & USA & 234 & 41 & 0.22 \\
\hline Sills et al., 2001 & USA & 18 & 36 & 0.35 \\
\hline Tsanadis et al., 2002 & Greece & 35 & 30 & 0.98 \\
\hline Lee et al.,2003 & Korea & 100 & 86 & 0.66 \\
\hline Orio et al., 2003 & Italy & 70 & 70 & 0.15 \\
\hline Palep-Singh et al., 2007 & UK & 9 & 21 & 0.36 \\
\hline Palep-Singh et al., 2007 & UK & 16 & 25 & 0.61 \\
\hline Choi et al., 2009 & Korea & 115 & 227 & 0.06 \\
\hline Bayram et al.,2010 & Turkey & 28 & 30 & 0 \\
\hline Karadeniz et al., 2010 & Turkey & 70 & 86 & 0 \\
\hline Idali et al., 2012 & Iran & 100 & 71 & 0.42 \\
\hline Jain et al.,2012 & India & 95 & 92 & 0.36 \\
\hline Kazerooni et al., 2013 & Iran & 60 & 120 & 0.007 \\
\hline Jiang et al.,2015 & China & 122 & 90 & 0.36 \\
\hline Naghavi et al.,2015 & Iran & 196 & 112 & 0.14 \\
\hline Qi et al.,2015 & China & 58 & 115 & 0.14 \\
\hline Carlus et al2016,Indo European & India & 100 & 93 & 0.36 \\
\hline Carlus et al.,2016,Dravidian & India & 156 & 168 & 0.58 \\
\hline Geng et al.,2016 & China & 236 & 175 & 0.06 \\
\hline Ozegowsa et a.,2016 & Poland & 99 & 168 & 0.49 \\
\hline Sazafarowska et al., 2016 & Poland & 56 & 76 & 0.08 \\
\hline Wu et al.,2016 & China & 257 & 244 & 0.23 \\
\hline Jiao et al.,2018 & China & 307 & 336 & 0.11 \\
\hline Almukhtar and Almohaidi,2019 & Iraq & 50 & 50 & 0.77 \\
\hline
\end{tabular}


medRxiv preprint doi: https://doi.org/10.1101/2020.06.15.20132324; this version posted June 19, 2020. The copyright holder for this preprint (which was not certified by peer review) is the author/funder, who has granted medRxiv a license to display the preprint in perpetuity.

It is made available under a CC-BY-NC 4.0 International license.

Table 2: Summary estimates for the odds ratio (OR) of MTHFR C677T in various allele/genotype contrasts, the significance level ( $p$ value) of heterogeneity test $\left(Q\right.$ test), and the $I^{2}$ metric and publication bias p-value (Egger Test).

\begin{tabular}{|l|l|l|l|l|l|}
\hline Genetic Models & Fixed effect & Random effect & $\begin{array}{l}\text { Heteroge } \\
\text { neity p- } \\
\text { value }(\mathbf{Q} \\
\text { test) }\end{array}$ & $\begin{array}{l}\mathbf{I}^{2} \text { (\%) } \\
\text { OR }(\mathbf{9 5 \%} \mathbf{~ C I}), \mathbf{p}\end{array}$ & $\begin{array}{l}\text { Publicati } \\
\text { on Bias } \\
\text { (p of } \\
\text { Egger's } \\
\text { test) }\end{array}$ \\
\hline Allele Contrast (T vs C) & $1.28(1.17-140),<0.0001$ & $1.18(1.01-1.38), 0.03$ & $<0.0001$ & 61.1 & 0.07 \\
\hline Co-dominant (Ct vs CC) & $1.34(1.17-1.59),<0.0001$ & $1.31(1.04-1.62), 0.017$ & 0.0002 & 57.92 & 0.77 \\
\hline Homozygote (TT vs CC) & $1.62(1.34-1.96),<0.0001$ & $1.37(1.0-1.89), 0.04$ & 0.0019 & 53.06 & 0.05 \\
\hline Dominant (TT+CT vs CC) & $1.39(1.23-1.58),<0.0001$ & $1.31(1.07-1.62), 0.008$ & 0.0002 & 57.99 & 0.40 \\
\hline Recessive (TT vs CT+CC) & $1.32(1.12-1.55), 0.0007$ & $1.10(0.82-1.47), 0.04$ & 0.001 & 55.06 & 0.01 \\
\hline
\end{tabular}

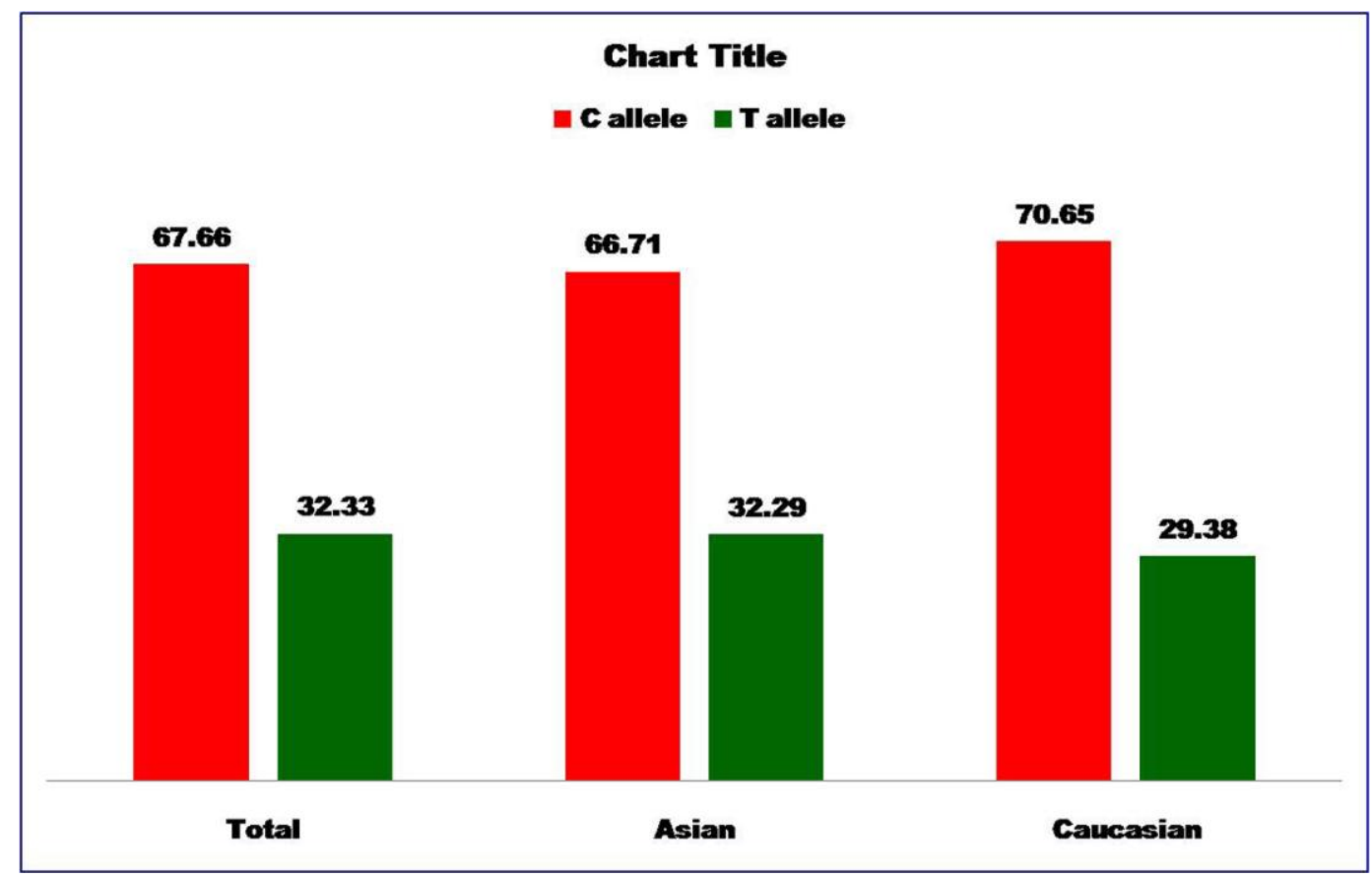

Figure 1.Bar diagram showing percentage of $\mathrm{C}$ and $\mathrm{T}$ allele frequencies in control group of total 24 studies, 16 Asian studies and 8 Caucasian studies. 


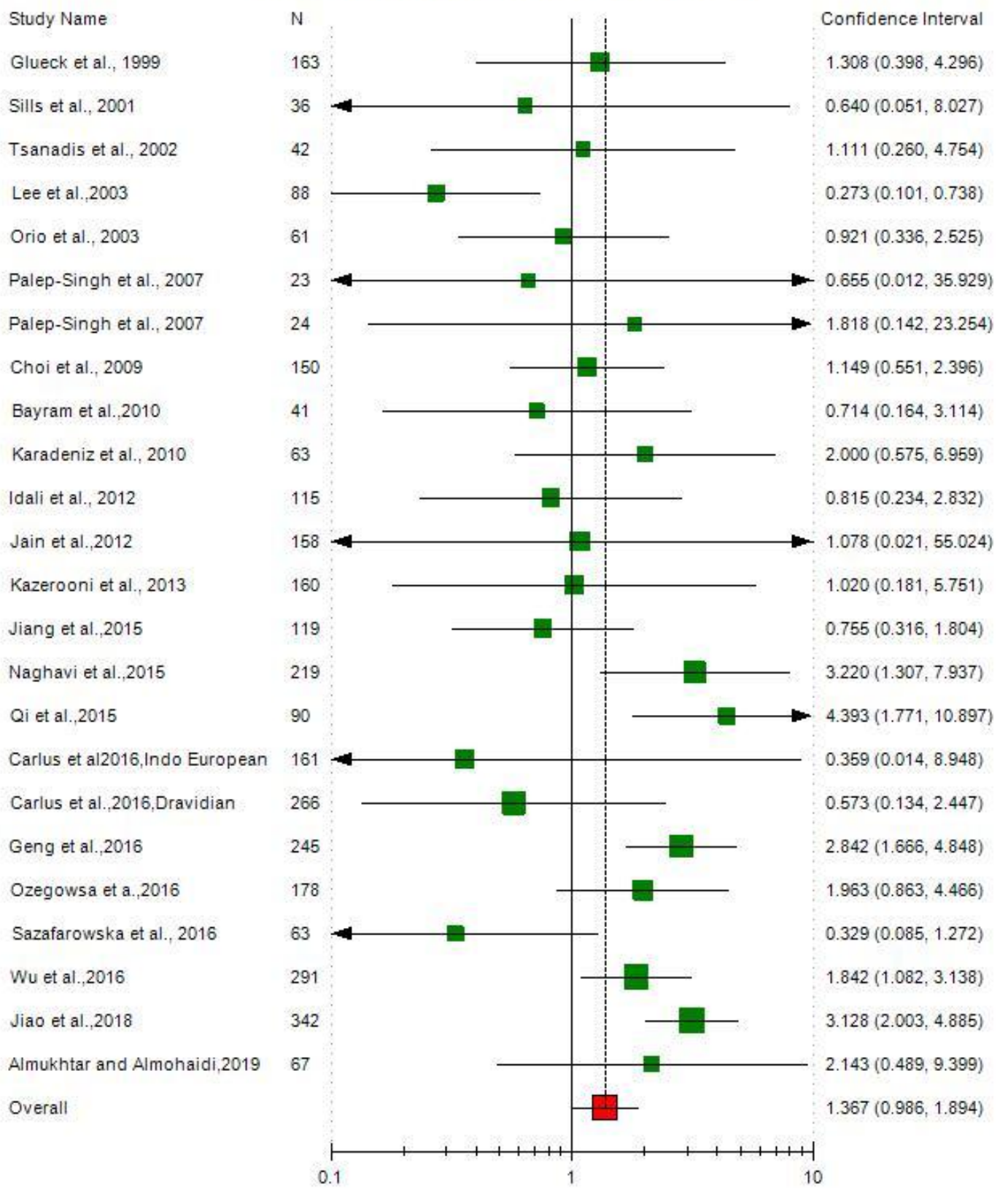

Figure 2. Random effect Forest plot of homozygote model (TT vs. CC) of total 24 studies of MTHFR gene C677T polymorphism. 
medRxiv preprint doi: https://doi.org/10.1101/2020.06.15.20132324; this version posted June 19, 2020. The copyright holder for this preprint (which was not certified by peer review) is the author/funder, who has granted medRxiv a license to display the preprint in perpetuity.

It is made available under a CC-BY-NC 4.0 International license .

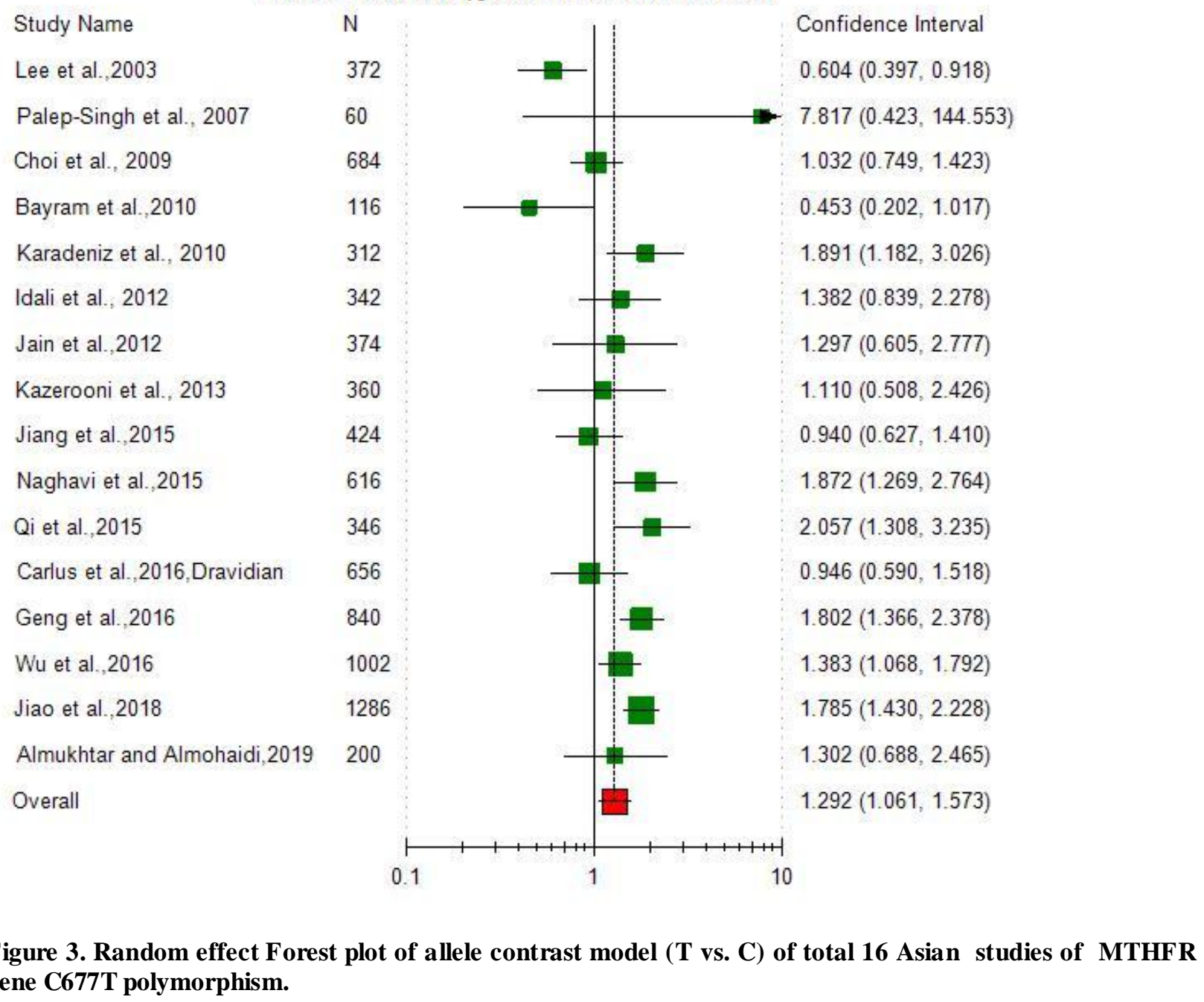


medRxiv preprint doi: https://doi.org/10.1101/2020.06.15.20132324; this version posted June 19, 2020. The copyright holder for this preprint (which was not certified by peer review) is the author/funder, who has granted medRxiv a license to display the preprint in perpetuity.

\section{It is made available under a CC-BY-NC 4.0 International license .}

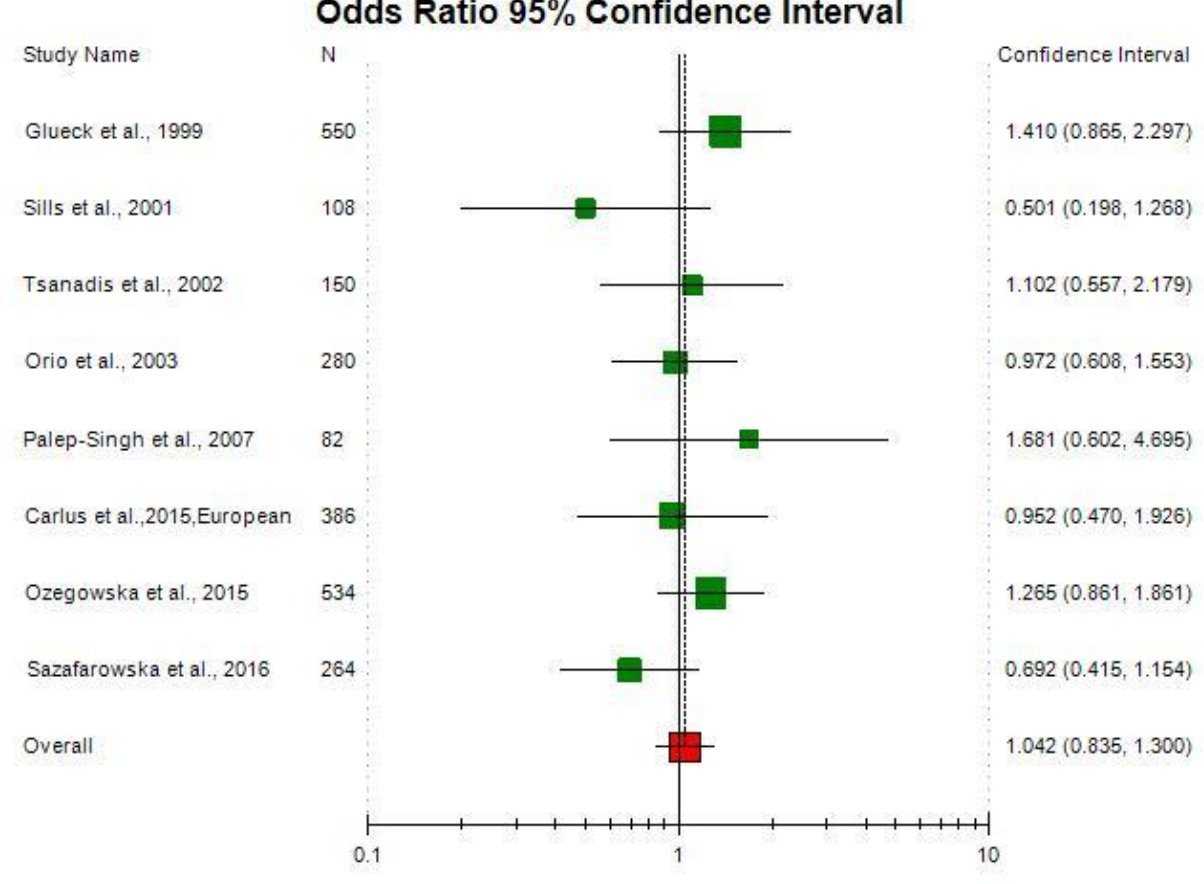

Figure 4. Random effect Forest plot of allele contrast model (A vs. G) of total 8 Caucasian studies of MTHFR gene C677T polymorphism.

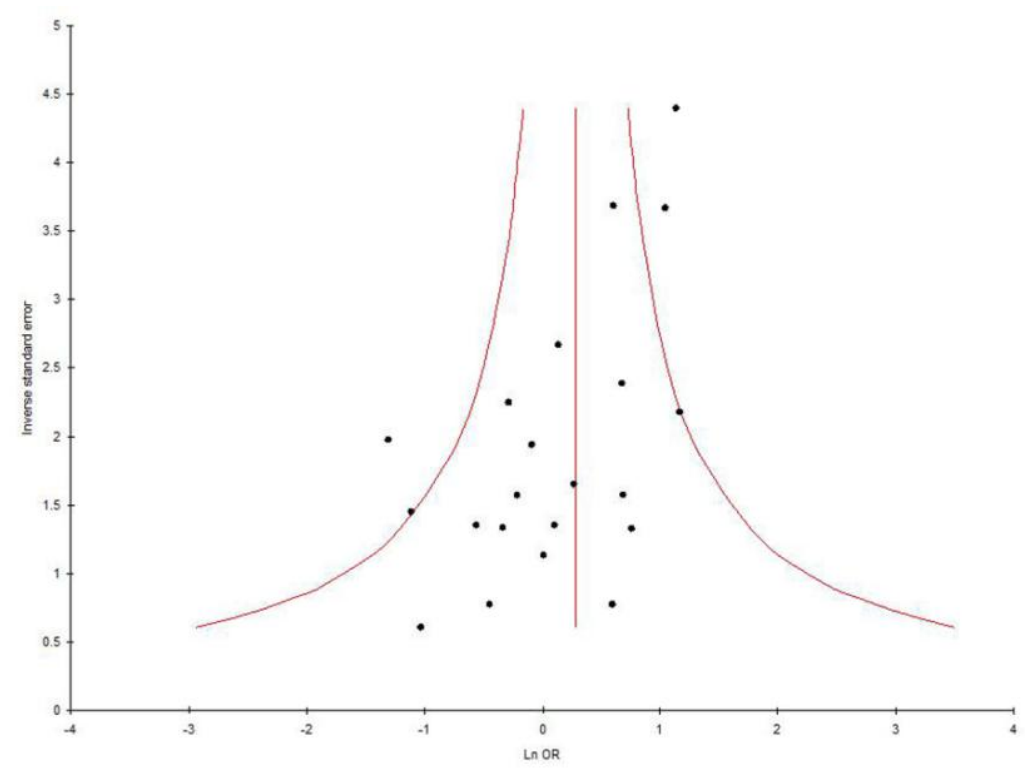

Figure 5 Funnel plot- precision by log odds ratio for allele contrast model ( $T$ vs. C) of total 24 studies of MTHFR gene C677T polymorphism. 